\title{
Pengembangan Buku Kartun Fisika Berbasis Kontekstual untuk Siswa SMP Kelas VIII pada Materi Gelombang dan Bunyi
}

\author{
Intan Fauziyyah, Eko Nursulistiyo \\ Program Studi Pendidikan Fisika Universitas Ahmad Dahlan \\ J1. Dr. Soepomo, SH., Janturan, Warungboto, Umbulharjo, Yogyakarta, Indonesia \\ Surat-e: intanfauziyyah@gmail.com
}

Telah disusun sebuah buku teks pelajaran dalam bentuk kartun. Buku ini bertujuan untuk membantu siswa dalam memahami konsep fisika tentang gelombang dan bunyi. Sebagian siswa berpendapat bahwa buku fisika yang mereka miliki tidak menarik karena disesaki tulisan dan rumus-rumus yang membingungkan. Pengembangan pada penelitian ini menggunakan model ADDIE yang terdiri dari tahap analisis (analysis), desain (design), pengembangan (development), implementasi (implementation), dan evaluasi (eveluation) Validasi produk memperoleh penilaian dari ahli materi sebesar 80,6 \%, ahli media sebesar 81,5\%, dan peer reviewers sebesar $85,4 \%$. Keseluruhan hasil penilaian termasuk dalam kategori SangatBaik (SB). Produk kemudian di ujicobakan kepada 20 siswa kelas IX SMP N 2 Lengkong Nganjuk menggunakan instrumen berupa angket. Hasil penilaian oleh guru IPA SMPN 2 Lengkong Nganjuk sebesar 9I,I6\% dan hasil rata-rata penilaian oleh 20 siswa kelas IX di SMPN 2 Lengkong Patianrowo sebesar 92,0\% dengan kategori Sangat Baik (SB).

\begin{abstract}
A learning text book had been compiled in a cartoon form. This book was aimed to help student absorb sound and wave concept slighter. Some students said that their regular physic book was not interesting because of full of texts and formulas. ADDIE was used in this research which stands for Analysis, Design, Development, Implementation, and Evaluation. By the evaluation from experts, the product gained $80,6 \%$ for the content, $81,5 \%$ for the media aspect, and by peer reviews $85,4 \%$ has gained. At overall score gained, the product could be categorized in very good level. 20 students of SMP N 2 Lengkong Nganjuk have implemented this product which then filld the survey to gain their responds. Based on the survey, it gained $92,0 \%$ and from their teacher 91,16\% which categorized in very good level.
\end{abstract}

Kata kunci: kartun fisika, gelombang, bunyi

\section{Pendahuluan}

Buku teks pelajaran hingga kini masih dianggap sebagai bahan ajar yang paling utama. Ini terbukti hampir di berbagai institusi pendidikan, dari jenjang yang paling dasar hingga yang paling tinggi, pada umumnya menggunakan buku teks pelajaran sebagai bahan ajarnya. Hal ini membuktikan pula bahwa keberadaan buku teks pelajaran masih merupakan bagian yang tidak terpisahkan dari proses pembelajaran yang berlangsung di berbagai institusi pendidikan kita saat ini. Buku teks pelajaran merupakan bagian penting dari kegiatan pembelajaran[I].

Buku teks yang mengacu pada kurikulum lama memberi siswa konsep yang harus dihafal, dan kurang mengajak siswa berpikir sebagai proses mengkontruksi pengetahuan dan pengalaman mereka. Artinya buku teks yang ada pada umumnya memberi siswa fakta, konsep, prinsip, dan prosedur yang harus dihafal, tetapi kurang memperhatikan bagaimana proses membelajarkannya melalui buku tersebut kepada siswa[2].

Menurut Milly R. Sonnerman dalam bahwa kartun dan media gambar merupakan salah satu dari bahasa visual yang mempunyai kelebihan dari pada media lain. Richard Gosselin, Senior Training Specialist Oglethorpe Power Corporation, menyatakan "Anda dapat menyuntikan energi melalui gambar. Energi dalam ruangan dapat menggairahkan pertemuan. Gambar menambah ragam baru dan mendorong peserta terlibat total dengan pengalaman pelatihannya"[3].

Berdasarkan hasil wawancara dengan guru mata pelajaran IPA Terpadu dan salah satu siswa kelas IX SMP 
Negeri 2 Lengkong Nganjuk, bahwa Fisika merupakan mata pelajaran yang penuh tantangan. Siswa masih merasa belum mampu memahami konsep Fisika yang dipelajari. Siswa berpendapat bahwa buku fisika yang mereka miliki tidak menarik karena disesaki tulisan dan rumus-rumus yang membingungkan. Oleh karena itu perlu adanya buku fisika yang menarik sehingga dapat menimbulkan rasa senang ketika membacanya.

\section{Kajian Pustaka}

Media pembelajaran dapat diklasifikasikan sebagai berikut[4]:

I) Media Berbasis Cetakan

Materi pengajaran berbasis cetakan paling umum dikenal adalah buku teks, buku penuntun, jurnal, majalah, dan lembar lepas. Teks berbasis cetakan menuntuk enam elemen yang perlu diperhatikan pada saat merancang, yaitu konsisten, format, organisasi, daya tarik, ukuran huruf, dan penggunaan spasi kosong

2) Media Berbasis Visual

Media Visual dapat memperlancar pemahaman dan memperkuat ingatan. Visual dapat pula menumbuhkan minat siswa dan dapat memberikan hubungan antara isi materi pelajaran dengan dunia nyata. Dalam proses penataan elemen media visual harus diperhatikan prinsip-prinsip desain tertentu, antara lain prinsip kesederhanaan, keterpaduan, penekanan dan keseimbangan. Unsur-unsur visual selanjutnya yang perlu dipertimbangkan adalah bentuk, garis, ruang, tekstur dan warna. Bentuk visual dapat berupa gambar representasi, diagram, peta, dan grafik.

3) Media Berbasis Komputer

Komputer berperan sebagai media dalam proses pembelajaran (computer Managed Intrucion, CMI). Format penyajian pesan dan informasi dalam CAI terdiri atas tutorial terprogram, tutorial intelijen, drill and practice, dan simulasi.

4) Media Berbasis Manusia

Media ini bermanfaat khususnya bila tujuan kita adalah mengubah sikap ingin secara langsung terlibat dengan pemantauan pembelajaran siswa. Media berbasis manusia mengajukan dua teknik yang efektif, yaitu rancangan yang berpusat pada masalah dan bertanya.

5) Media Berbasis Audio-Visual

Media ini menggabungkan antara media visual dengan penggunaan suara. Pendahuluan pada penyampaian pelajaran media ini harus dipertunjukan sesuatu yang dapat menarik perhatian semua siswa. Kontiniutas program dapat dikembangkan melalui penggunaan cerita atau permasalahan yang memerlukan pemecahannya.

Salah satu bentuk komunikasi grafis, kartun merupakan suatu gambar interpretatif yang menggunakan simbolsimbol untuk menyampaikan suatu pesan secara cepat dan ringkas, atau sesuatu sikap terhadap orang, situasi, dan kejadian-kejadian tertentu. Kartun biasanya hanya mengungkap esensi pesan yang harus disampaikan dan menuang kedalam gambar sederhana secara detail menggunakan simbol-simbol serta karakter yang mudah dikenal dan dimengerti secara tepat [5].

Pembelajaran kontekstual merupakan konsep belajar dan mengajar yang membantu guru mengaitkan antara materi yang diajarkan dengan situasi nyata siswa dan mendorong siswa membuat hubungan antara pengetahuan yang dimilikinya dengan penerapan dalam kehidupan mereka sebagai keluarga, masyarakat, alam sekitar, dan dunia kerja sehingga siswa mampu membuat hubungan antara pengetahuan yang dimilikinya dengan penerapan dalam kehidupan mereka sebagai anggota keluarga, warga negara dan pekerjaan[6].

\section{Metode Penelitian/Eksperimen}

Penelitian ini dilakukan dengan metode "Penelitian Pengembangan” atau Research and Development (R\&D). Brog dan Gall dalam Sugiyono[7] menyatakan bahwa dalam pendidikan, $\mathrm{R} \& \mathrm{D}$ merupakan metode penelitian yang digunakan utuk mengembangkan atau memvalidasi produk-produk yang digunakan dalam pendidikan dan pembelajaran. Pada penelitian ini yang akan dikembangkan adalah media pembelajaran buku kartun Fisika berbasis kontekstual untuk siswa kelas VIII SMP pada materi gelombang dan bunyi. Prosedur yang digunakan dalam penelitian ini menggunakan model ADDIE. Model pengembangan terdiri dari lima tahap utama, yaitu analisis (analysis), desain (design), pengembangan (development), implementasi (implementation), dan evaluasi (eveluation).

\section{Hasil Penelitian dan Pembahasan}

Sampul depan buku kartun fisika seperti terlihat pada gambar I. Berdasarkan analisis penilaian oleh ahli materi, ahli media, dan penilaian peer reviewers diperoleh hasil seperti terlihat pada gambar 2. Berdasarkan pada gambar 2 , terlihat bahwa hasil penilaian berada pada rentang $80 \%$ ke atas. Ini mengindikasikan bahwa produk yang telah dihasilkan termasuk dalam kategori Sangat Baik, sehingga layak untuk diujicobakan ke sekolah. 

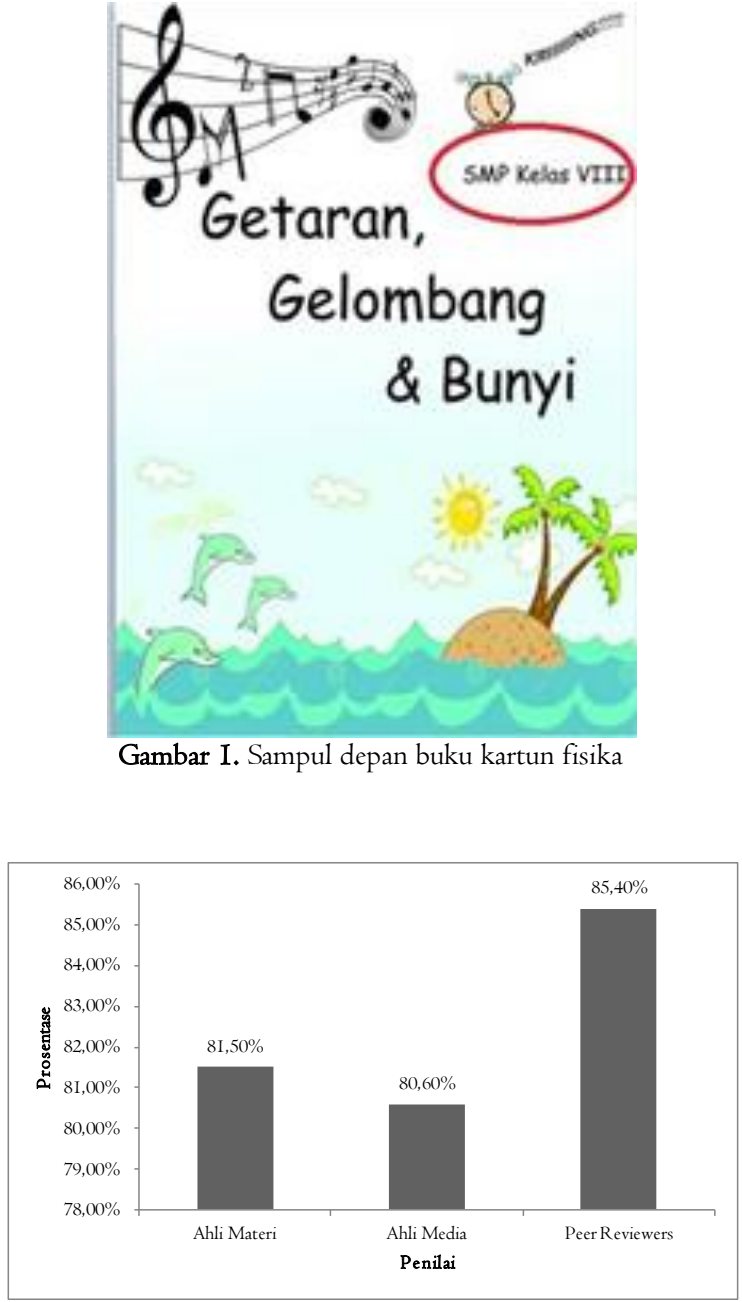

Gambar 2. Penilaian produk oleh ahli

Ujicoba produk dilakukan di SMP Negeri 2 Lengkong, Nganjuk, Jawa Timur. Ujicoba ini dilakukan ke siswa dan guru IPA yang ada di sekolah tersebut. Ujicoba ke siswa untuk melihat bagaimana respon siswa terhadap produk dan telah dihasilkan. Sedangkan ke guru lebih pada kesesuaian produk dengan kurikulum dan kultur sekolah. Hasil ujicoba ini ditampilkan pada gambar 3 .

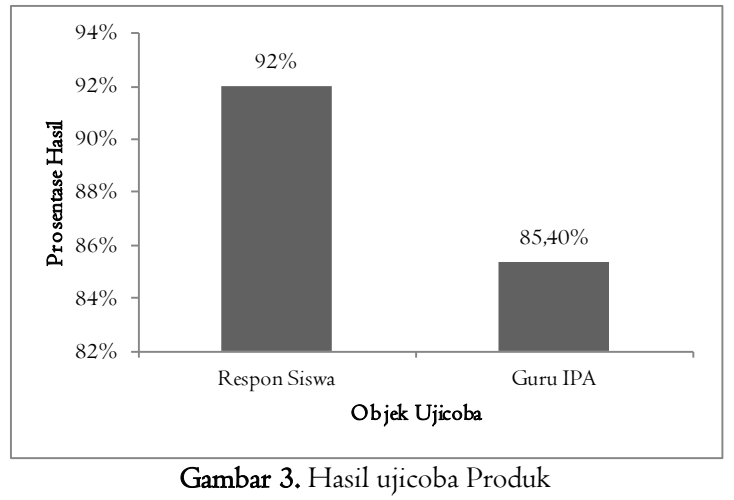

Dari gambar 2 terlihat bahwa respon siswa terhadap produk sangat baik dengan skor lebih dari 90\%. Sedangkan guru IPA memberikan penilaian $85,40 \%$ yang juga masuk dalam kategori sangat baik.

Hasil ini menunjukan bahwa produk layak untuk digunakan sebagai media pembelajaran bagi guru. Produk juga bisa digunakan sebagai buku pendamping buku teks pelajaran yang biasa dipakai guru di sekolah.

\section{Kesimpulan}

Telah dihasilkan produk berupa buku kartun fisika sebagai media pembelajaran gelobang dan bunyi. Produk ini telah dinilai kelayakannya oleh para ahli dan masuk kategori sangat baik. Hasil uji coba produk juga menunjukkan bahwa buku sangat layak untuk digunakan sebagai pendamping buku teks pelajaran sekolah.

\section{Kepustakaan}

[1] Prastoeo, A. (2013). Panduan Kreatif Membuat Bahan Ajar Inovatif. Yogyakarta: DIVA Press.

[2] Komalasari, K. (2013). Pembelajaran Kontekstual Konsep dan Aplikasinya. Bandung: Refika Aditama.

[3] Supriadi. (2008). Penggunaan Kartun Matematika dalam Pembelajaran Matematika.

[4] Sanjaya, W. (2007). Strategi Pembelajaran Berorientasi Standar \& Proses Pendidikan. Wina Sanjaya: Kencana Media Group.

[5] Direktorat Pembinaan SMA. (2010). Panduan Pengembangan Bahan Ajar: Departemen Pendidikan Nasional. Jakarta.

[6] Yustiniadi, D. (1996). Tentang Kartun. Semarang: Effhar \& Dahara Prize.

[7] Sugiyomo. (20I4). Metode Penelitian Kuantitatif, Kualitatif, dan R\&D. Bandung: Alfa Beta. 